\title{
Sulphatide in islets of Langerhans and in organs affected in diabetic late complications: a study in human and animal tissue
}

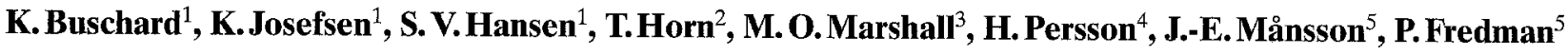 \\ ${ }^{1}$ Bartholin Instituttet, Kommunehospitalet, Copenhagen, Denmark \\ ${ }^{2}$ Department of Pathology, Herlev Hospital, University of Copenhagen, Denmark \\ ${ }^{3}$ Department of Diabetes Immunology, Novo-Nordisk, Bagsværd, Denmark \\ ${ }^{4}$ Department of Anatomy and Cell Biology, University of Göteborg, Sweden \\ ${ }^{5}$ Department of Clinical Neuroscience, Section of Psychiatry and Neurochemistry, University of Göteborg, Mölndals sjukhus, \\ Mölndal, Sweden
}

\begin{abstract}
Summary Sulphatide has been found in rat islets of Langerhans and anti-sulphatide antibodies have been demonstrated in patients with insulin-dependent diabetes mellitus. Using a specific monoclonal antibody, Sulph I, directed against sulphatide, we investigated the in situ distribution of this glycolipid immunohistochemically; furthermore, the sulphatide concentration was determined in several organs and cells by thin-layer chromatography. The islets of Langerhans in all species examined, mouse, rat, pig, and monkey were intensively stained but exocrine tissue remained unlabelled. The sulphatide concentration in human islets was $150 \pm 46 \mathrm{pmol} / 100$ islets. The only glycolipid-antigen detected was sulphatide. Regarding other tissues, sulphatide was found to be
\end{abstract}

located in distal tubules in the kidney, peripheral nerves, distinct scattered spot-like structures in the choreoid layer of the eye, the ovum, and peripheral granulocytes. Sulph I injection in mice showed homing to kidney tubules. Lung, heart, liver, adrenal, spleen, lymph node and thymus were not stained by Sulph I. Thus, the distribution of sulphatide shows an association with organs known to be affected in diabetes, either initially or in late complications. [Diabetologia (1994) 37: 1000-1006]

Key words Diabetes mellitus, glycolipids, sulphatide, islets of Langerhans, kidney, peripheral nerves, eye, ovary, thin-layer chromatography.
Sulphatide is known as a neural epitope present in large amounts in central and peripheral nervous tissue mainly in connection with myelin [1]. Recently we demonstrated sulphatide in rat pancreatic islet cells [2] and found anti-sulphatide antibodies in patients with newly-diagnosed insulin-dependent diabetes mellitus as well as in BB rats [3]. Sulphatide consists of a galactosyl group bound to a lipid core composed of sphingosine and fatty acid, and with a sulphate group attached at the 3'-position. Biochemical analyses have shown that mammalian kidney tissues are rich in sulphated glycolipids, including sul-

Received: 26 January 1994

and in revised form: 17 May 1994

Corresponding author: Dr. K. Buschard, Bartholin Instituttet, Kommunehospitalet, DK-1399 Copenhagen K, Denmark

Abbreviations: FACS, fluorescence-activated cell sorter. phatide [4], but the cellular distribution and subcellular localization is still uncertain. Sulphatide was reported to be enriched in human uterine endometrium during the secretory phase [5]. Biochemical examination is needed to provide information about the quantity of the substance and also identification of the molecule. However, the cellular localisation of sulphatide and its distribution within the cell requires specific antibodies for use in immunohistochemistry. Such studies are few due to the previous lack of suitable antibodies. Zalc et al. [6] used a rabbit polyclonal antiserum to immunohistochemically demonstrate the localization of sulphatide to the brain and other investigators have used the monoclonal antibody 04 to investigate the sulphatide in myelin formation [7]. However, the absence of defined specificity of the used antibodies limits the validity of these studies.

The availability of a specific monoclonal antibody against sulphatide, Sulph I [8], has opened new possi- 
bilities for performing specific studies. This antibody does not crossreact with non-lipid sulphated compounds but reacts with glycolipids restricted to sulphatide, sulphated lactosylceramide and seminolipid [8]. The aim of the present study was to investigate the occurrence and concentrations of sulphatide in human and animal tissues using immunohistochemistry and thin-layer chromatography.

\section{Materials and methods}

Tissue origin. Monkey tissue (pancreas, kidney, nerve) was obtained from a male Macaca facicularis monkey, between 2 and 5 years old. Pig tissue (pancreas, kidney, nerve) originated from a 5-month-old female Yorkshire pig. Rat tissues (pancreas, kidney, nerve, eye, ovary, uterine tube, uterus, testis, and lung, heart, liver, adrenal, spleen, lymph node, thymus) were obtained from non-diabetic adult $B B$ rats and Lewis rats. Islets of Langerhans were isolated from male Lewis rats, male Wistar Furth rats, and from male non-diabetic BB rats. The rats were about 10 weeks of age and purchased from Møllegaard (Ll. Skensved, Denmark). Mouse tissues (pancreas, kidney, nerve) were examined from 8-week-old male BALB/c and 7-week-old female non-diabetic NOD mice. Fifteen 8 week-old male BALB/c mice, and six female NOD mice, 7 weeks old (non-diabetic) or 14 weeks old (diabetic) were used in antibody homing experiments. The mice originated from Bomholtgaard (Ry, Denmark).

Human pancreatic tissue was obtained from six kidney donors in the Scandinavian "Scantransplant" programme. The use of the tissue for scientific investigations had been approved by the Ethical Committee of the Danish Ministry of Health. The mean age was $42.1 \pm 4.9$ years. The pieces of pancreata examined weighed between 3 and $5 \mathrm{~g}$. Peripheral blood granulocytes originated from nine (six male and three female) healthy human volunteers, $35.0 \pm 3.5$ years of age.

Anti-glycolipid monoclonal antibodies. Sulph I, as previously described [8], was produced by immunizing BALB/c mice with sulphatide coated on Salmonella minnesota bacterial membranes. A subsequent fusion with mouse myeloma cells resulted in a hybridoma-producing anti-sulphatide antibody of subclass IgG1. It reacts with sulphatide (3-sulphogalactosylceramide) and the closely-related structures sulpholactosylceramide and seminolipid [8]. It recognizes the terminal part galactose-3- 0 and part of the ceramide portion and therefore does not crossreact with sulphated proteins [8].

Light microscopy procedures. The indirect immunoperoxidase staining procedure was used. Frozen tissue sections $(5 \mu \mathrm{m}$ thick) were fixed in acetone at $20^{\circ} \mathrm{C}$ for $5 \mathrm{~min}$, and after washing were incubated for $60 \mathrm{~min}$ with Sulph I (130 mg/l buffer), diluted $1: 100$ in $0.05 \mathrm{~mol} / 1$ phosphate buffered saline, $\mathrm{pH} 7.2$. After a second wash, the sections were incubated for $30 \mathrm{~min}$ with peroxidase conjugated, rabbit anti-mouse immunoglobulin ( $\mathrm{P} 260 ;$ Dako, Copenhagen, Denmark) diluted 1:50 in phosphate buffered saline. Before use this was absorbed with serum from an animal of the same species as the examined tissue. Following a short rinse in phosphate buffered saline incubation with peroxidase substrate solution was carried out at $20^{\circ} \mathrm{C}$ for $30 \mathrm{~min}$. This consisted of $8 \mathrm{mg}$ 3-amino-9-ethylcarbazole diluted in $1 \mathrm{ml}$ acetone and $20 \mathrm{ml} 0.05 \mathrm{~mol} / \mathrm{l}$ acetate buffer, $\mathrm{pH}$ 5.0 , added $10 \mu \mathrm{l} 30 \% \mathrm{H}_{2} \mathrm{O}_{2}$ immediately before use. The sec- tions were counterstained in Mayer's haematoxylin for $2 \mathrm{~min}$ and after $5 \mathrm{~min}$ in running tap water coverslips were mounted with Aquamount (BDH, Poole, Dorset, UK). Control preparations were treated similarly except for buffer or monoclonal anti-human CD8 antibody (M 707; Dako) as primary layer. All controls were completely negative.

Antibody homing studies. The experimental mice were given i. v. 100 ul $(130 \mathrm{mg} / \mathrm{l})$ Sulph I, diluted 1:4 in phosphate buffered saline. BALB/c mice were killed $2,4,8,16,32 \mathrm{~h}$ after the antibody injection $(n=2)$, respectively, whereas both diabetic and non-diabetic NOD mice $(n=4)$ were killed $4 \mathrm{~h}$ after antibody administration. Pancreas, kidney, and brain were removed immediately and prepared for histological analyses as described above except for the primary antibody labelling. Control (5 BALB/c and 2 NOD) mice were given monoclonal anti-human CD8 IgG1 antibody (M 707, Dako) and otherwise treated similarly.

Isolation of rat islets and beta and non-beta islet cells. Islets of Langerhans from male Lewis rats, Wistar Furth rats, and BB rats were isolated under sterile conditions by a collagenase digestion technique described previously [9]. In brief, a collagenase (Sigma, St Louis, Mo., USA) and DNase (Worthington, Freehold, N.J., USA) mixture was injected into the pancreatic duct immediately after the animal had been killed. The pancreas was removed and shaken vigorously $2 \times 6 \mathrm{~min}$ in a water bath at $37^{\circ} \mathrm{C}$. After washing and aspiration, the tissue was centrifuged on a Ficoll gradient (Pharmacia, Uppsala, Sweden) for $10 \mathrm{~min}$ at $500 \mathrm{~g}$. Following washing three times the remaining exocrine tissue was removed with a pipette under a stereo microscope. The amount of sulphatide was determined in six different portions of between 1200-2100 Lewis rat islets, in three different portions of between 1000-3000 Wistar Furth islets, and in three different portions of between 500-1000 BB rat islets. Lewis islets used for isolation of beta and non-beta islet cells were resuspended in RPMI-1640 with $20 \mathrm{mmol} / \mathrm{l}$ HEPES buffer, $1 \%$ normal human serum, $4 \mathrm{mmol} / \mathrm{l}$ L-glutamine, $24 \mathrm{mmol} / 1 \mathrm{NaHCO}_{3}, 0.5 \%$ Penicillin-Streptomycin $(10000$ $\mathrm{IU} / \mathrm{ml} / 10000 \mu \mathrm{g} / \mathrm{ml}$, Gibco, Paisley, UK), adjusted to $\mathrm{pH} 7.35$ and incubated overnight at $4^{\circ} \mathrm{C}$. The following day the islets were incubated with Dispase (Boehringer Mannheim, Mannheim, Germany) for $3 \times 8 \mathrm{~min}$ at $37^{\circ} \mathrm{C}$ and after repeated aspirations the islet cells were separated.

Islet cell sorting using fluorescence-activated cell sorter (FACS). The islet cell sorting was performed on a FACStar Plus (Becton Dickinson, Mountain View, Calif., USA) operating with a 70$\mu \mathrm{m}$ nozzletip. Autofluorescence was elicited using $488 \mathrm{~nm}$ excitation and $515-545 \mathrm{~nm}$ emission. Two populations were readily visible [10], one low-fluorescence, low-scatter fraction containing $97.8 \pm 1.5 \%(n=5)$ endocrine, non-beta cells and one highscatter, high fluorescence containing $96.7 \pm 2.6 \%(n=5)$ beta cells; the quality of the sortings was checked by electron microscopy, the contaminating cell types were exocrine cells, stroma cells or lymphocytes. Measurements of glucagon and insulin in the supernatant after incubation of sorted islet cell subsets, showed for the non-beta-cell fraction that $95 \%$ of the produced hormone was glucagon, further indicating that the majority of the endocrine cells in this fraction were alpha cells. The sorted cells were morphologically well preserved. Five different beta-cell fractions of between 150,000-200,000 cells and five different non-beta-cell fractions of 100,000 cells were determined for sulphatide.

Isolation of human islets. The human islets were isolated from two male kidney donors (ages 27 and 40 years) using a collage- 

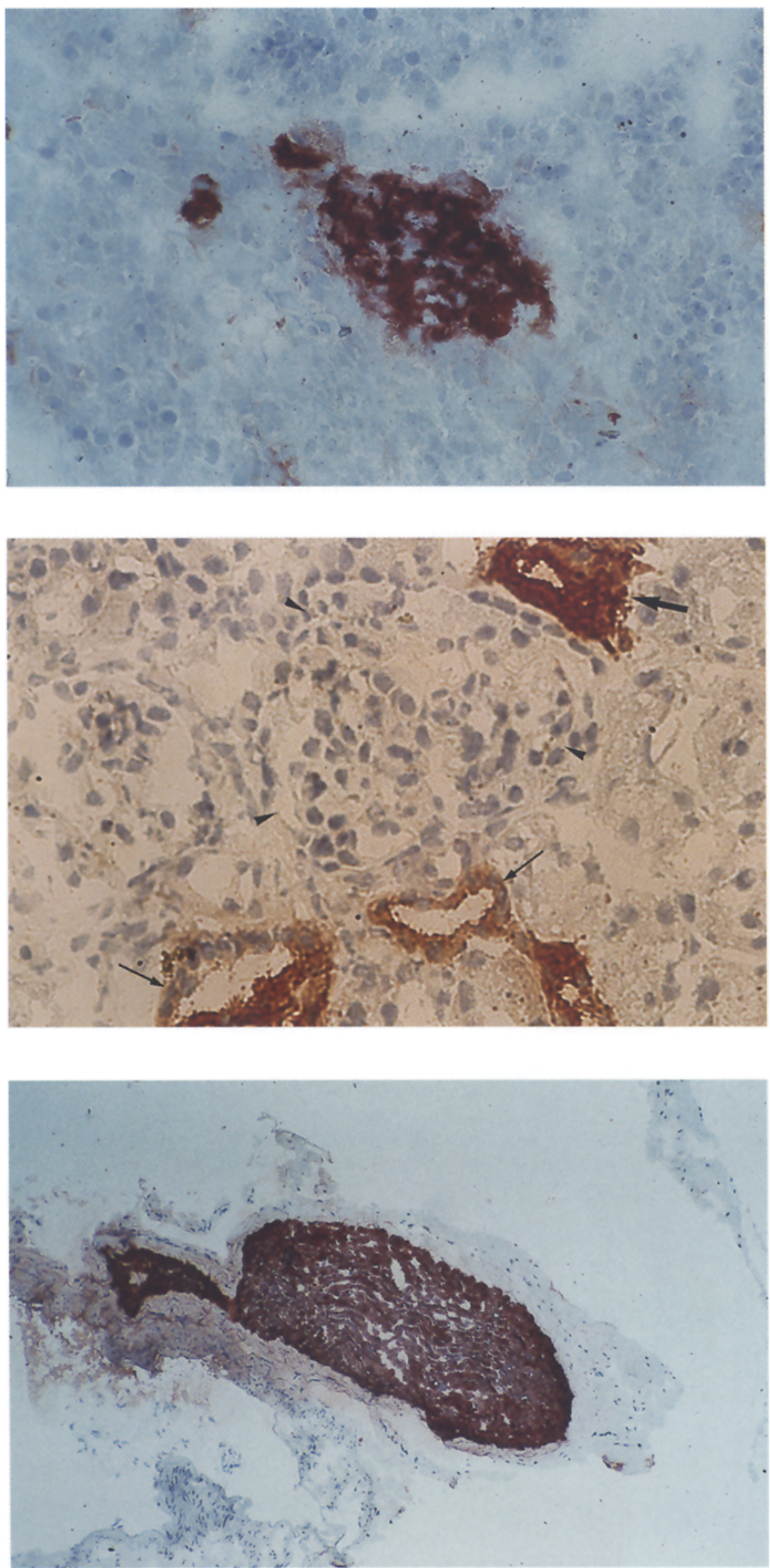

Fig. 1. Sulph I-stained monkey pancreas section (all histological illustrations are from frozen sections). Original magnification $\times 100$. Islet cells are strongly positive whereas stromal cells as well as exocrine elements are negative

Fig. 2. Sulph I-stained pig kidney section $(x 150)$. Next to the glomerulus (outlined by arrowheads) a strongly stained vascular pole is seen (thick arrow). Note the scattered staining of proximal tubules (thin arrows)

Fig. 3. Sulph I-stained rat vagal nerve $(\times 25)$ Note the intense staining illustrating that both myelin sheaths and nerve fibers are labelled 
nase method as previously described [11]. The use of the islets for research was approved by the Ethical Committee. They were a gift from Dr. Pujol-Borrell, Barcelona, Spain.

Analysis of peripheral granulocytes. Peripheral granulocytes were isolated as described earlier [12]. The cells were incubated with Sulph I, diluted 1:100. A seond antibody was fluorescein isothiocyanate-conjugated rabbit anti-mouse immunoglobulin (Dako). The cells were analysed on a FACStar Plus (Becton Dickinson) using a granulocyte gate. Anti-CD15 (Becton Dickinson) labelled granulocytes were used as quality control of the cells.

Determination of sulphatide. Extraction of lipids, including sulphatide, from various tissues including isolated islets was performed with chloroform/methanol/water ( $4: 8: 3$, by volume) as described previously [13]. Sulphatide was then isolated by phase partition. Chloroform/methanol $(2: 1, \mathrm{v} / \mathrm{v})$ was added to obtain a final chloroform/methanol/water ratio ( $4: 2: 1$, by volume). Sulphatide was determined in the lower phase. With the use of ${ }^{14} \mathrm{C}$-labelled sulphatide the recovery was found to be $98 \pm 2 \%(n=20)$. The amount of sulphatide, sulphated lactosylceramide, and/or seminolipid in the islets was determined by a modification of the thin-layer chromatography (TLC) overlay technique previously described [14]. An aliquot of the lower phase containing extract was chromatographed on thinlayer chromatography-plates (Marchery-Nagel, Düren, Germany) using chloroform/methanol/water ( $65: 25: 4$ by volume) as developing solvent. The plates were first incubated with the monoclonal antibody Sulph I and bound antibody detected with an alkaline phosphatase conjugated goat anti-mouse $\operatorname{IgG}+\operatorname{IgM}(\mathrm{H}+\mathrm{L})$ antibody (Jackson Laboratories, West Grove, Penn., USA). Structurally characterized standards of sulphatide and sulphated lactosylceramide and seminolipid were chromatographed on the same TLC plate as the samples and the absorbance was quantitated by densitometric scanning.

The human islets ( 3000 and 3500 , respectively, from the two donors) were extracted in two portions, whereafter the lipid extracts were divided into four fractions. These were partitioned and analysed separately.

\section{Results}

Neural tissue as well as islets of Langerhans, some specific kidney and eye structures, oocytes, and peripheral blood granulocytes were distinctly marked by staining with Sulph I, as described in detail below. Rat lung, heart, liver, adrenal, spleen, lymph nodes or thymus tissue were not labelled by Sulph I.

In pancreas sections from mice, rats, pig, and monkey (Fig.1) a bright staining of the islets of Langerhans was noticed whereas the exocrine tissue remained unlabelled. All cells of the islets were stained, and also several small islets containing one, two or a few cell(s) only were labelled.

In kidneys of Lewis rats, BALB/c mice, the pig (Fig. 2) and monkey, an intense staining of the wall of the juxtaglomerular arterioles and of the macula densa area was seen. Other parts of the tubular system, mainly representing distal tubules, were stained by Sulph I. An irregular pattern was, how- ever, found with some tubules showing an intense staining and others being unlabelled. Glomeruli were negative.

As expected there was an intensive staining by Sulph I of neural tissue. In peripheral nerves including the vagal nerve from rat (Fig. 3), pig, and monkey, an intense staining was seen. The labelling was confined to the nerve proper including both nerve fibers and myelin sheaths, whereas the perineural sheath was negative.

In the eyes from rats and rabbits, Sulph I staining revealed two labelling sites. In choreoidea a distinct spotted staining was seen (Fig. 4). The precise nature of the stained area is uncertain but could represent nerve fibers. The retinal layers were unlabelled. Also, the ciliary processes were stained; the basal membrane complex of the ciliary epithelium was labelled.

In the rat ovary, Sulph I distinctly labelled the ovum, whereas the follicle epithelium, the theca and rest of the ovary were unstained (Fig.5). In the rat oviduct (uterine tube), parts of the epithelium were labelled, whereas the uterus was negative. In the rat testis a dense, complete staining inside each tubule was noted, and in epididymus an intense labelling of the spermatozoa was seen.

Regarding peripheral blood granulocytes, $98.1 \pm$ $0.5 \%( \pm$ SEM $)$ of the isolated and gated cells were CD 15-positive indicating that they were granulocytes. Of these cells $96.4 \pm 0.6 \%$ were labelled with Sulph I.

Antibody homing study. In all the kidneys of the Sulph I-injected animals a distinct labelling of tubules was seen similar to that in Figure 2 . The intensity of the staining was highest in kidneys from mice killed $4 \mathrm{~h}$ after the antibody infusion but labelling was seen in all the samples $(2-32 \mathrm{~h})$. In NOD mice killed after $4 \mathrm{~h}$, the same tubular labelling was seen in 7-week-old non-diabetic animals, whereas 14week-old diabetic NOD mice besides a very intense tubular labelling in addition showed staining of mesangial cells in the glomeruli. In all the examined animals the brain and pancreas were unlabelled indicating absence of Sulph I antibody homing in these organs. Tissues from control mice injected with anti-human CD8 antibody were all unstained.

Determination of sulphatide. Sulphatide was found in similar concentrations in Lewis rat beta cells $((n=5)$ $13 \pm 3$ pmol/100,000 cells) and in Lewis rat non-beta islet cells $((n=5) 16 \pm 5 \mathrm{pmol} / 100,000$ cells $)$. In rat islets the sulphatide concentrations were $(n=6)$ $410 \pm 50 \mathrm{pmol} / 100$ Lewis rat islets, $(n=3) 87 \pm 20$ $\mathrm{pmol} / 100 \mathrm{BB}$ rat islets, and $(n=3) 181 \pm 50 \mathrm{pmol} /$ 100 Wistar Furth rat islets, respectively. In isolated human islets of Langerhans sulphatide was detected and determined to $(n=4) 150 \pm 46 \mathrm{pmol} / 100$ islets. 

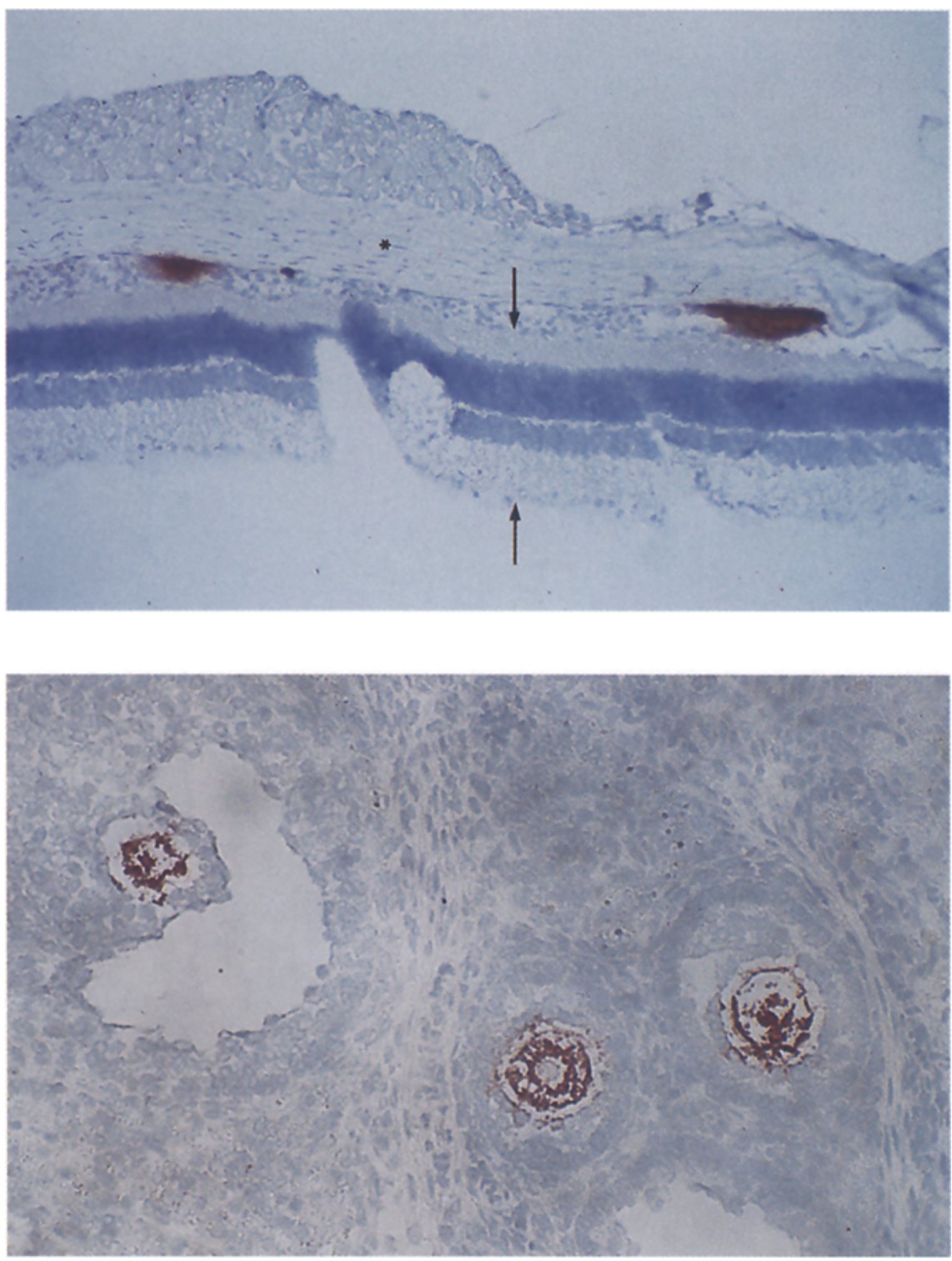

Fig.4. Sulph I-stained rat eye section $(\times 25)$. Spotty staining in the choreoid layer. The retina (double arrow) and sclera (asterisk) are unstained
Fig.5. Sulph I-stained rat ovary $(\times 100)$. Three follicles are demonstrated, each showing a heavily stained oocyte
A

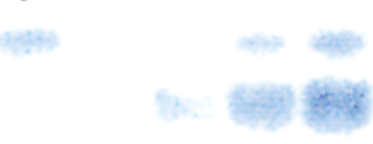

\section{$1 \quad 2 \quad 3 \quad 4 \quad 5$}

\section{1}

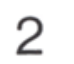

4

Fig.6. Thin-layer chromatography of glycolipid antigens in rat testis (A) and human islets of Langerhans (B). The procedure is described in Materials and methods. The lower phase lipid extract is chromatographed and stained with the Sulph I antibody. No staining was observed in the upper phase lipid extract (data not shown). Panel A: lane 1 , lower phase lipids corresponding to $0.04 \mathrm{mg}$ wet weight of testis; lanes 2-5, standards of seminolipid (upper bands) 25, 50, 100, and 200 pmol and of sulphatide (lower bands) 10,20,40, and 80 pmol. Panel B: lane 1, lower phase lipids corresponding to 33 islets of Langerhans; lanes 2-4 standards of sulphatide (20, 40 , and 80 pmol). Seminolipid (upper band, $500 \mathrm{pmol}$ ) and sulphated lactosylceramide (lower band, $40 \mathrm{pmol}$ ) is added in lane 2 and 3 , respectively
The amount of sulphatide in human pancreatic tissue was found to be $(n=6) 84 \pm 12 \mathrm{nmol}$ sulphatide $/ \mathrm{g}$ wet pancreas tissue. In Lewis rat kidney the sulphatide concentration was $(n=8) 278 \pm 13 \mathrm{nmol} / \mathrm{g}$ wet tissue and in Lewis rat ovary $(n=8) 7 \pm 1 \mathrm{nmol} / \mathrm{g}$. In all these cells and tissues the only Sulph I sensitive glycolipid antigen that could be detected was sulphatide, and no sulphated lactosylceramide or seminolipid was found. Also, in the Lewis rat eyes only sulphatide could be detected, whereas in Lewis rat testis no sulphatide was found but exclusively seminolipid $((n=4) 4913 \pm 54 \mathrm{nmol} / \mathrm{g})$. The staining of glycolipid antigens in human islets of Langerhans and rat testis is shown in Figure 6 which shows the different migration of the antigens detected by Sulph I. 


\section{Discussion}

Using histochemistry and thin-layer chromatography this study demonstrates the presence of sulphatide in islets of Langerhans, in tubular kidney structures, in neural tissue, in certain spots of the choreoid layer and the ciliary processes in the eye, in peripheral granulocytes, and in the oocyte, whereas the testis solely contains seminolipid.

The reactivity of the used monoclonal Sulph I antibody is restricted to three lipids carrying a sulphated epitope attached to a galactose group; other antigens of a protein nature could therefore be excluded [8]. The distinction between sulphatide, sulphated lactosylceramide, and seminolipid was made unequivocally by thin-layer chromatography.

In islets of Langerhans, the amount of sulphatide may differ because of different islet sizes but the magnitude in rats and human islets was similar. Assuming that $1 \%$ of a pancreas consists of islets, the sulphatide concentration in human islets should be $8.4 \mu \mathrm{mol} / \mathrm{g}$ islet tissue, which is about one third of the concentration in the white matter of the human brain (23 $\pm 6 \mu \mathrm{mol} / \mathrm{g}$ wet weight [15]).

Interestingly, sulphatide is demonstrated in tissues involved in the primary diabetic lesion and in the late complications. In the islets of Langerhans, the insulitis process primarily destroys the beta cells, but in most patients all endocrine cells in the islets (including non-beta cells) have disappeared after 5-10 years.

Many patients with insulin-dependent diabetes develop diabetic nephropathy after a disease duration of 10-20 years or more. Mainly the glomeruli are affected and clinical signs and symptoms are albuminuria and hypertension. Recently, we have shown that Sulph I labels the mesangium in the diabetic glomeruli [2]. Staining of kidney tubules with Sulph I is in good agreement with an earlier demonstration of sulphatide in these structures [16].

Neuropathy of varying severity is commonly seen in diabetic patients after some years duration of the disease. In irreversible neuropathy due to glycaemic causes, demyelinated nerve fibres are found. In the eye virtually all diabetic patients of long disease duration show retinopathy simplex which is seen by ophthalmoscopy as scattered dots in the retina. The relation to our histological findings is uncertain at the moment.

Regarding the ovary, no late diabetic complications are usually assigned to this organ. However, it has been shown that diabetes-prone BB rats have a lower number of offspring which have an altered sex ratio [17].

The location of sulphatide to tissues affected by the diabetic disease is interesting, but it is not known if there is a possible pathophysiological role of sulphatide in the development of diabetes and diabetic complications. An immunological involvement in the de- velopment of diabetic late complications is not thought to occur but has nevertheless been suggested $[18,19]$. Regarding the biological function of sulphatide, this is not fully elucidated, but it has been reported that sulphatide binds to a number of proteins including blood coagulation factors, glycolipid transport proteins, and endorphin, and sulphatide has been suggested to be involved in processes such as ion transport, biomembrane fusion and endocytosis [20].

In conclusion, the distribution of sulphatide in different body tissues shows an association to tissues (organs) known to be affected in the diabetes disease. Future research should clarify whether sulphatide may actually play a pathogenetic role in diabetogenesis.

Acknowledgements. We are grateful to Ms. K. Andersson, Ms. B. Dellheden, Ms. B. M. Rynmark, Ms. Å. Källen, Ms. H. Kjærgaard, Ms. E. Christiansen, Ms. S. Sørensen and Ms. M. Bæksted for excellent technical assistance. This study was supported by grants from the Swedish Medical Research Council (Project No B94-03X-09909-03A), the Danish Diabetes Association, and the Danish Medical Research Council.

\section{References}

1. Norton WT, Autilio LA (1966) The lipid composition of purified bovine brain myelin. J Neurochem 13: 1213-1222

2. Buschard K, Josefsen K, Horn T, Larsen S, Fredman P (1993) Sulphatide antigen in islets of Langerhans and in diabetic glomeruli, and anti-sulphatide antibodies in type 1 diabetes. APMIS 101: 963-970

3. Buschard K, Josefsen K, Horn T, Fredman P (1993) Sulphatide and sulphatide antibodies in insulin-dependent diabetes mellitus. Lancet 342: 840

4. Mårtensson E (1966) Sulfatides of human kidney. Isolation, identification, and fatty acid composition. Biochim Biophys Acta 116: 296-308

5. Kubushiro K, Kojima K, Mikami M et al. (1989) Menstrual cycle-associated alteration of sulfogalactosylceramide in human uterine endometrium: possible induction of glycolipid sulfation by sex steroid hormones. Arch Biochem Biophys 268: 129-136

6. Zalc B, Monge M, Dupouey M, Hauw JJ, Baumann NA (1981) Immunohistochemical localization of galactosyl and sulfogalactosyl ceramide in the brain of the 30-day old mouse. Brain Research 211: 341-354

7. Dubois-Daleq M, Armstrong RC (1992) The oligodendrocyte lineage during myelination and remyelination. In: Martenson RE, (ed) Myelin: biology and chemistry. CRC Press, Boca Raton, Fl, USA, pp. 81-122

8. Fredman P, Mattsson L, Andersson K et al. (1988) Characterization of the binding epitope of a monoclonal antibody to sulphatide. Biochem J 251: 17-22

9. Buschard K, Aaen K, Horn T, van Damme J, Bendtzen K (1990) Interleukin 6 is a functional and structural modulator of beta-cells from islets of Langerhans. Autoimmunity 5: 185-194

10. Van de Winkel M, Pipeleers D (1983) Autofluorescence-activated cell sorting of pancreatic islet cells: purification of insulin-containing B-cells according to glucose-induced changes in cellular redox state. Biochem Biophys Res Com 114: 835-842 
11. Vives M, Sarri Y, Conget I et al. (1992) Human islet function after automatic isolation and bovine serum albumin gradient purification. Transplantation 53: 2443-2445

12. Eggleton P, Gargan R, Fisher D (1989) Rapid method for the isolation of neutrophiles in high yield without the use of dextran or density gradient polymers. J Immunol Methods 121: 105-113

13. Svennerholm L, Fredman P (1980) A procedure for the quantitative isolation of brain gangliosides. Biochim Biophys Acta 617: 97-109

14. Fredman P, Månsson J-E, Bigner SH, Wikstrand CJ, Bigner DD, Svennerholm L (1990) Gangliosides in the human glioma cell line U-118MG grown in culture or as xenograft in nude rats. Biochim Biophys Acta 1045: 239-244

15. Rosengren B, Fredman P, Månsson J-E, Svennerholm L (1989) Lysosulphatide (galactosylsphingosine-3-0-sulphate) from metachromatic leukodystrophy and normal human brain. J Neurochem 52: 1035-1041
16. Zalc B, Helwig JJ, Ghandour MS, Sarlieve L (1978) Sulphatide in the kidney: How is this lipid involved in sodium chloride transport. FEBS Letters 92: 92-96

17. Kjaer TW, Kornerup Hansen A, Josefsen K, Pedersen C, Buschard K (1991) Changed sex ratio in BB rat offspring. Scand J Lab Animal Science 18: 23-27

18. Rabinowe SL (1990) Immunology of diabetic and polyglandular neuropathy. Diabetes Metab Rev 6: 169-188

19. Brown FM, Watts M, Rabinowe SL (1990) Inheritance of anti-autonomic nervous system autoantibodies in type I diabetes. Diabetes 39 [Suppl 1]: 125A (Abstract)

20. Vos JP, Lopes-Cardozo M, Gadella BM (1994) Metabolic and functional aspects of sulfogalactolipids. Biochim Biophys Acta 1211: 125-149 